\title{
LISE HILDEBRANDT-ERIKSEN
}

\section{KROP, SIND OG SJÆL: ERFARINGER MED EN KROPSTERAPI}

Denne artikel er baseret på mine egne erfaringer som Ma-uri-massør og på interaktion med andre Ma-uri-mass $\emptyset$ rer i perioden 1992-94. Udgangspunktet er derfor ikke klassisk etnografisk - en objektivering af De Andres livsverden. Udgangspunktet er en subjektivitet, der udspringer fra min erfaring med de utallige roller, som min kultur lægger ud for mig som menneske, hvoraf rollerne som antropolog og som Ma-uri-massør blot er nogle. I årevis oplevede jeg det, som om min kultur ikke alene formede valgene og adskillelsen mellem forskellige roller, men at min kultur også påtvang mig en adskillelse af hoved og krop, af det intuitive og intellektet, af kroppen og sjælen. Disse erfaringer bragte mig i kontakt med Ma-uri-massagen. Dette første og noget tilfældige møde blev en kærkommen anledning til at gøre endnu et forsøg på at skabe sammenhæng i min fragmenterede verden, ikke mindst i min oplevelse af krop/sjæl-adskillelsen. Endvidere blev Ma-uri-massagen, som en sekundær gevinst, en indirekte anledning til at teste antropologen i mig selv med hensyn til, hvor langt jeg er villig til at gå for at lære et fremmed kulturelt univers at kende. At stille sin afklædte krop og sjæl til rådighed for fremmede hænders og begrebers manipulation kan måske siges at være en særlig erfaring $\mathrm{i}$ et antropologisk univers.

I de to et halvt år, jeg har beskæftiget mig med Ma-uri-massagen, har jeg gjort, hvad der var mig menneskeligt muligt for at leve mig ind i og leve med en kultur, et univers og erfaringsmåder, der er totalt forskellige fra, hvad jeg nogensinde før har oplevet. Jeg har foretaget adskillige rejser $\mathrm{i}$ min egen krop, i andres kroppe, i andre universer og til Aotearoa - den lange, hvide skys land (New Zealand). Jeg har diskuteret mine erfaringer med venner og bekendte inden for Ma-uri-massagen, med mine klienter og ikke mindst med maorier under min rejse til New Zealand i 1993. Min rolle som antropolog har været aktiveret som i en parentes i en større sammenhæng. Jeg har været og er fortsat mere deltager end observatør og analytiker, selv om jeg ikke kan frasige mig min baggrund som antropolog, lige så lidt som jeg kan frasige mig baggrunden for mine andre roller som social aktør. Ma-uri-massage er en meget krævende sag for den udøver, der ønsker at mestre håndværket optimalt. Undervejs i min læreproces med Ma-uri-massagen erfarede jeg, at mine til tider ynkelige forsøg på at agere ,rigtig“" antropolog med notesbog og distanceret observation afskar mig fra væsentlige erfaringer og informationer. På den måde blev min brug af notesbogen også ubevidst et forsøg på at undslippe oplevelser og 
erfaringer, som jeg ikke ønskede at få, eller som jeg ikke var parat til at absorbere. Oplevelser med Ma-uri-massage kan være meget specielle. Jeg har været og er til en vis grad stadig usikker over for de mest grænseoverskridende kropsoplevelser.

På et tidspunkt blev fristelsen til at lade antropologen træde ud af sin parentes for stor. Jeg begyndte at omformulere mine erfaringer med Ma-uri-massagen for at forstå dem antropologisk. Jeg begyndte så småt at læse antropologisk faglitteratur igen. Jeg fandt et behageligt leje for min rolle som Ma-uri-aktør, og jeg fandt et behageligt leje for min rolle som antropolog.

Læseren må altså forestille sig, at denne artikel er skrevet fra det sted i det antropologiske tid og rum, hvor informanten lige er begyndt at forklare sin kultur og bliver bevidst om den på en ny måde. Jeg prøver at objektivere en for mig indforstået kultur og gøre den forståelig for læsere, der ikke har mine kulturelle erfaringer. Artiklen er således med Bourdieus ord barnets fors $\emptyset \mathrm{g}$ på at gøre sig forståelig over for sine forældre, det afprøver forskellige sprog, indtil budskabet er gået igennem (Rabinow 1977:166). Jeg har ønsket at formidle både specifikke og generelle erfaringer. De følgende afsnit må derfor ses som et fors $\emptyset \mathrm{g}$ på at få et medicinsk antropologisk overblik eller indblik i min egen subjektivitet, hvorfra denne artikel er produceret. Læseren må forestille sig forfatteren sidde i sit køkken - symbolsk placeret i rummet mellem skrivebordet og massagebriksen fordybet i læsningen af Scheper-Hughes og Lock: The Mindful Body:

Det er åbenlyst, at biomedicinen stadig er fanget i den cartesianske dikotomi og de dertil relaterede oppositioner mellem natur og kultur, naturlig og overnaturlig, virkelig og uvirkelig. Hvis og når vi tænker reduktionistisk på sind-krop, så er det fordi det ,er godt for os at tænke " på den måde. At tænke det anderledes, ved at bruge en radikal forskellig metafysik, ville indebære, at vi skulle se bort fra vores egen opfattelse af verden og dens kulturbundne definitioner af virkelighed (Scheper-Hughes \& Lock 1987:30).

Ma-uri-massagen som healingaktivitet overskrider grænserne for vestlig kropsopfattelse og måderne, hvorpå erfaringerne hermed opnås. Det kræver mod at overskride oplevelserne af de grænser, vores kultur sætter for vores kropserfaring. Dette mod er en nødvendig ingrediens i Ma-uri-massørens arbejde. Et svigtende mod kan afskære den aktive Ma-uri-massør fra nødvendige erfaringer og redskaber i massagearbejdet.

Artiklen er således baseret på mine erfaringer med kommunikation med forskellige Ma-uri-mass $\emptyset$ rer. Det er en kommunikation, der er foregået via kropserfaringer, samtaler og breve. Drømme, symboler, massage og telefoner er blot nogle af ingredienserne i denne kommunikation. Artiklen igennem anvender jeg både betegnelserne Ma-uri-akt $\varnothing-$ rerne og „os“,,vi“" som benævnelse for deltagere i Ma-uri-massage-uddannelsen. Det gør jeg vel vidende, at „vi“ sandsynligvis ikke er repræsentativt for alle Ma-uri-massører. Bortset fra det første dagbogscitat, som stammer fra min egen dagbog, er de øvrige eksempler blevet til i dialoger med forskellige Ma-uri-massører. Hvem de tilhører, er uvæsentligt i denne sammenhæng. Her må det være nok at lade dem stå som råb, udsagn, håb og kærtegn fra forskellige niveauer i kropserfaringen.

\section{Ma-uri-institutionen og rekrutteringsgrundlaget}

Institutionaliseringen af Ma-uri-massagen i Danmark er personificeret i en maori-healer 
og dennes danske ægtefælle. Parret formidler massagen gennem et uddannelsesforløb, individuelle behandlinger samt afholdelse af kurser og release-klinikker. Institutionens fysiske og administrative rammer er undselige, og undervisning samt individuelle massager finder sted på skiftende lokaliteter og i mere eller mindre offentlige klinikker.

Uddannelsen til Ma-uri-mass $ø$ r er tilrettelagt som en serie af selvstændige kursusforløb, der strækker sig over 2-4 dage. Uddannelsen består endvidere af individuelle forløb, hvor vi som deltagere selv modtager massage og træner vores færdighed som massører. Uddannelsen til Ma-uri-massør kan omfatte en rejse til New Zealand i Ma-uriinstitutionens regi. Uddannelsen igennem veksler deltagerne mellem at være aktive udøvere af massage og at være aktive modtagere af massage.

Ma-uri-massagen anvendes af alle typer behandlere fra børnepsykiatere og socialpædagoger til alternative behandlere. Endvidere rekrutteres mennesker, hvis livsforløb viser tegn på sygdom eller anden krise.

\section{Ma-uri-massage - en kropsterapi}

I min dagbog har jeg berettet følgende indtryk fra mit første møde med Ma-uri-massagen:

Jeg ankommer til en spejderhytte midt i en norddansk skov. Det er midt om vinteren, bortset fra en enkelt gøende hund ved en nærliggende gård, så ånder alt vinterfred. En række biler uden for spejderhytten signalerer, at her er nogen. Spændt træder jeg indenfor og m $\varnothing-$ des af sko og overtøj i entreen. Jeg ankommer til den tid, jeg har aftalt med min massør, og forventer at blive modtaget med en eller anden introduktion til, hvad det her egentlig går ud på. Jeg regner bestemt med det. Mine tanker afbrydes brat i entreen af en dør, der åbnes ind til fællesrummet, hvor jeg i et glimt når at opfange en intens massageaktivitet. Ud ad døren kommer en mand iført pelshue og brun ulden frakke, idet han kommer mig i møde med ordene: „Hej med dig. Tag bare alt dit tøj af og læg dig op på et 'bord', så kommer der nogen og ta'r dig“. Der går et gys igennem mig. Manden er næsten ude af døren og væk i en bil, før jeg når at registrere, hvad budskabet går ud på. ,Det må være shamanen“, tænker jeg. Ingen såkaldt normal dansker ville finde på at byde en gæst velkommen på den måde, for ikke at tale om hvordan en behandler modtager sin patient eller klient.

Jeg bliver pludselig i tvivl om, hvad jeg egentlig har at gøre her. Jeg bliver også i tvivl om min egen identitet og rolle. Hvad forventes der af mig? Er jeg patient, klient, mig selv eller bare en klump kød? Jeg føler mig pludselig overbevist om, at jeg på Guds nåde og barmhjertighed har givet mig et eksotisk slagtehus i vold, og at hvis jeg nogensinde slipper ud derfra, så er det i småstykker eller forvandlet til en dæmon, eller det der er værre.

Mine bange anelser bekræftes, da jeg yderst forsigtigt åbner døren til fællesrummet. En dampende varme slår mig i møde, samtidig med at en høj og fremmedartet musik strømmer ind i mine ører. Synet af en halv snes svedige massører, der ihærdigt lader hænder og arme glide over svedige og olieglinsende kroppe, mens de bevæger sig dansende rundt om „ofrene“ brænder sig for evigt fast på nethinden. Nogle af massørerne står med spidse albuer vinkelret ned i kødet på kroppene, hvilket afstedkommer stønnen, klynken, gråd og jamren - lyde, der konkurrerer ihærdigt med båndmusikken.

Min mass $ø r$ vinker mig smilende nærmere, og jeg må spørge mig selv, om hun er en engel eller en djævel. Er dette her Dantes Inferno eller Porten til Paradis? Noget midt imellem er det i hvert fald ikke. Stum og tavs synker jeg ned på gulvet og giver mig hen i en observationsrus. Her er alt andet end fredeligt!

Ma-uri-massage er betegnelsen for en massage og healingsteknik med rødder i det poly- 
nesiske områdes shamanisme. ${ }^{1}$ Navnet Ma-uri er en variation af Mauri, der betegner det essentielle livsprincip. Maori-terapeuten Te Hata beskriver Mauri således:

Essensen i Mauri er, at det er den principielle livskraft i og omkring alle levende ting. Det responderer på hver af de følelser, vi har i os som mennesker (Cowperthwaite 1992).

Mauri forstået som den essentielle livskraft er et almindeligt kendt begreb i maorisamfundet. Omskrivningen af Mauri til Ma-uri må betragtes som en art varemærke for Ma-uri-institutionen som terapeutisk praksis.

Ma-uri-massagen er kendetegnet ved at være en massage og healingsteknik, der udføres til tonerne af polynesiske sange og musikstykker. Ma-uri-massagens grundbevægelser indøves gennem traditionelle polynesiske danse. Ma-uri-massagen ses derfor af og til omtalt som dansemassage. Ma-uri-massagen adskiller sig fra andre polynesiske massageformer ved, at der anvendes lette tryk med albuen til at bearbejde særlige punkter på kroppen. Denne teknik omtales med det engelske ord release, hvilket henviser til, at Ma-urimassagen virker som en forløsning af fysiske, mentale og sjælelige blokeringer.

Dans og smerte kan være måder at opnå ændrede bevidsthedstilstande på (ScheperHughes \& Lock 1987:15). Dette synes at være tilfældet for Ma-uri-aktørerne, idet dansen kan bringe aktørerne i en tranceagtig tilstand, hvor gængse grænser (fysiske såvel som mentale og sjælelige) opløses. Smerten i forbindelse med release bevirker i nogle tilfælde ,ud-af-kroppen-oplevelser“, fremkomst af symboler, der står for aktørernes indre blik samt gennemlevning af fragmenter af ,tidligere liv“. Sagt med Scheper-Hughes og Locks ord, så er smerten for kroppen, hvad psykiatri og medicin er for patienten:

Tortur er en henvendelse til sjælen via kroppen; nutidens psykiatri og medicin henvender sig til kroppen via patientens sind og sjæl (ibid.:26).

\section{Et massageforløb}

Personen, der skal modtage massagen, tager tøjet af, lægger sig på maven med hovedet hvilende i massagebriksens hovedst $ø$ tte, hvorefter mass $\varnothing$ ren dækker personen med et lagen. Massøren starter med at placere sine hænder på personens skuldre for at opnå kontakt og tillid. Efter en stund lader massøren sine hænder bevæge sig ned over personens krop, der stadig er tildækket. Massøren er f.eks. opmærksom på kolde og varme steder, hårde og bløde områder samt åndedrættet. Herefter trækkes tildækningen tilbage fra skulderen til midt på kroppen, og massøren fordeler opvarmet olie i én glidende bevægelse fra skulder til midt på kroppen og ud på armene. Kroppen masseres først almindeligt, dvs. uden brug af albue i ca. 1/2 time. Herved arbejdes hele kroppen igennem, samtidig med at massøren får en fornemmelse for, hvordan resten af forløbet skal gribes an. Den del af massagen, hvor forløsningen af kropslige blokeringer finder sted og som blandt andet kan indebære anvendelse af albuetryk, udføres nu i ca. 1/2 time. I denne fase vil personen kunne opleve, at fysiske spændinger løsnes, og at eventuelle psykiske traumer dukker frem og forløses i gråd. En del personer beretter om, at tilstande som angst, vrede, frygt, had og afmagt transformeres til livgivende tilstande som lettelse, glæde og frihed.

Efter denne fase slutter massøren af med at massere kroppen blidt til stille musik. Herved bringes kroppen i en rolig og hvilende tilstand. Hver enkelt kropsdel berøres i langsomme, glidende bevægelser i overensstemmelse med deres indplacering i kosmos - 
højre arm strækkes mod himmelen (Ranginui - det maskuline element), og venstre arm og ben strækkes mod jorden (Papatuanuku - det feminine element). Berøringen i denne fase er en anerkendelse af de enkelte kropsdeles funktion og nærmest sakrale status. Seancen afsluttes med at kroppen „ofres“ til universet. Massøren lægger sin venstre underarm på personens overkrop med sin albue ved personens mave og hånden hvilende på hjertet og strækker samtidig sin højre arm mod universet. På dette stadie vil personen, der modtager massagen, ofte være i en søvnlignende tilstand, hvorfra massøren efter en kort hvileperiode vil kalde vedkommende tilbage, og massagen er afsluttet. En kvinde beretter i det følgende én af sine første oplevelser med Ma-uri-massage:

Jeg kom for at få massage, fordi jeg havde problemer med min mave, og jeg ønskede, at der blev gjort noget ved det. Jeg sagde ikke noget om det. Der bliver i det hele taget brugt meget få ord. Efter at massøren havde masseret hele min krop, tog hun fat på min mave, mens jeg lå med forsiden nedad på massagebriksen. Hun lod sine hænder glide ind under min mave og lod sine knoer køre meget langsomt hen over mit maveskind. Det var ekstremt smertefuldt, men det føltes rigtigt. Jeg kunne via massørens berøring mærke en masse hårde knuder i min mave. Hver gang hun kom til et hårdt punkt, standsede hun. Det føltes som at få en lang spids syl stukket ind i sig. Jeg fik kvalme, jeg græd, og jeg skreg. Jeg fik lyst til at kaste op, men kunne ikke. Jeg kunne mærke de dér hårde knuder i min mave, det var vrede og måske had. Det strømmede op fra maven og ud af halsen på mig. Jeg skreg ikke længere - jeg brølede! Jeg vidste ikke, der kunne være så meget volume i mig! Jeg mistede tidsfornemmelsen. Forløbet kunne have varet en halv time, en time eller mere. Jeg var ligeglad, jeg ønskede bare at komme af med det hele. Pludselig var det nok. Jeg kunne ikke mere. Massøren afsluttede behandlingen. Bagefter var jeg meget lettet og taknemmelig. Jeg følte virkelig, jeg havde fået den hjælp, som jeg var kommet for at få. Jeg følte mig som født påny. Min mave var helt blød og varm.

Eksemplet indeholder en række elementer, som både viser karaktereren af Ma-urimassage og rollerne som udøver og modtager. Personen, der modtager en massage, henvender sig ofte til Ma-uri-massøren med et konkret problem, som hun ønsker at få løst. Det er karakteristisk, at den nonverbale kommunikation antager en terapeutisk karakter, og at klienten føler tillid og tryghed under og efter behandlingen. Forløsningen af fysisk og psykisk smerte, som er målet for en Ma-uri-massage, sker i dette tilfælde i kraft af et samarbejde mellem massøren og klienten. I dette samarbejde er det massørens opgave intuitivt at fornemme, hvad klienten har brug for. Tabet af tidsfornemmelsen er typisk i et massageforløb, og det er i dette tidsrum, der kan opstå særegne kropsoplevelser i form af billeder, drømmetilstande og symboler.

\section{Et kursusforløb}

Et enkelt Ma-uri-massagekursus strækker sig normalt over to en halv dag fra fredag aften til søndag eftermiddag. Disse kurser forløber meget forskelligt, selv om de indeholder nogle faste holdepunkter. Det er disse, jeg vil opholde mig ved her. Kurserne indledes med en traditionel maori-velkomstceremoni, hvor maorihealeren „hilser“ huset og de naturlige omgivelser. Herefter byder han aktørerne velkommen med en tale, der ofte indeholder aspekter af maorimytologi, hvorefter han synger en sang. ${ }^{2}$ Dernæst byder maorihealerens ægtefælle velkommen på tilsvarende vis. Initiativet er nu overladt til os 
aktører, som hver især forventes at besvare værternes udfordring med en større eller mindre tale (ofte indeholdende tanker og overvejelser over, hvad det er, den pågældende $\emptyset$ nsker at opnå med netop dette kursus) efterfulgt af en sang, gerne sunget i fællesskab.

Når alle har ydet deres bidrag til velkomsten, påbegyndes den traditionelle maorihilsen - hongi. Alle hilser på hinanden ved efter tur at trykke panden mod den andens pande i en let bevægelse. Velkomstceremonien er nu tilendebragt, afstandsbarrierer mellem aktørerne og værterne og mellem aktørerne er brudt - fællesskabet er etableret.

Efter disse indledende manøvrer anvendes resten af aftenen til meditation eller foredrag i fællesrummet umiddelbart efter, at et let aftensmåltid er indtaget. Resten af kurset forløber som en vekselvirkning mellem meditation, massage, supervision og erfaringsudveksling mellem aktørerne. Alle aktiviteter undtagen spisning og nattes $\emptyset$ v foregår i fællesrummet. Der er derfor tale om kollektive seancer, hvilket jeg kort vil opholde mig ved. Scheper-Hughes og Lock beskriver kollektive healing-ritualer således:

I kollektive healingritualer sker der en sammenblanding, en forening af sjæl/krop, selv/anden, individ/gruppe, som på hovedsageligt nonverbale og endda før-refleksive måder udvirker, at den syge person „føles“ tilbage til en tilstand af velvære og helhed, og som genskaber den sociale krop (Scheper-Hughes \& Lock 1987:29).

Dette kommer tydeligt til udtryk på Ma-uri-massagekurserne. Gråd, latter, musik og dansende massører synes at flyde sammen i en organisk helhed, hvor disse enkeltdele synes at kommunikere ubevidst, hvorved der fremkaldes forskellige kropsreaktioner, herunder release.

\section{Krop og kosmos}

Kroppen er ifølge Ma-uri-institutionen indskrevet i en forbundethed med alt levende på jorden og i universet. Kroppen forstås som et spejl af universet, hvor kroppens mindste dele - celler og disses bestanddele - kan iagttages som et mikrokosmos over for makrokosmos - universets sol-, måne- og stjernesystemer. Denne kropsepistemologi formidles blandt andet igennem meditationsseancer, hvor aktørerne i liggende hvileposition lytter til maorihealerens tale om forskellige emner som f.eks. ,healing energy“, ,healing anger, fear and hate" og ,healing guilt“. Gennem talen bringes kroppen i en søvnig tilstand, hvor der, efter maorihealerens udsagn, kan opnås kontakt til det ubevidste hos aktørerne. Følgende meditationssekvens illustrerer en forståelse af kroppen som bestående af både det fysiske, sind og sjæl og som forbundet med kosmos:

Denne tale handler om at åbne dit indre selv. Denne tale handler om at åbne din krop og tillade alle de små celler, hvert eneste væsen i din krops rige, dit univers, din krop, at hver eneste lille celle skal føles vigtig og en del af dig som gudsskaberen af dit univers... Du består ikke kun af den fysiske form, du er et univers. Og ligesom der er tusinder og tusinder af stjerner i universet, så er der også i din krop tusinder og tusinder af sjæle i deres eget rige. Fra et atom til et molekyle, fra et molekyle til et sandkorn, fra et sandkorn til en sten, fra en sten til en strand, fra en strand til en $\emptyset$ i havet og fra et hav i et ocean, fra et ocean i en verden, en verden $i$ et solsystem, og et solsystem $i$ en galakse $i$ et univers og et univers i en unitron, og en unitron i en uniark, og det er skabelsens kerne fra et atom til et molekyle til et sandkorn... ${ }^{3}$ 
Taler eller meditationer som denne åbner for aktørernes kreativitet og fantasi. Meditationer tillader symboler eller visualiseringer at træde frem i bevidstheden. Effekten viser sig i talrige oplevelser, hvor vi under massage kan opleve kroppen i en kosmisk væren. Følgende beretning er blot én af mange erfaringer med krop i relation til kosmos:

Jeg sidder sammen med en flok mennesker, som jeg har samlet. Det er noget, Gud har pålagt mig. Jeg skal sørge for, at der ikke går panik i dem på grund af et vulkanudbrud. Jeg ser, at vi bliver til støv, og at vi blandes. Tiden var inde, til at vi skulle dø. Selv om vi er opløst i st $ø$ v og partikler, så eksisterer vi stadig. Vi oplever en forbundethed med hinanden og med kosmos. Dernæst oplever jeg, at jeg ligger i fosterstilling inde i jorden. Jeg ligger trygt og godt. Pludselig gribes jeg af angst for, hvem der skal være min far. Så åbner jorden sig i en sprække, og jeg ser en stor lysende stjerne. Jeg falder til ro i visheden om, at jeg trygt kan vente.

Opfattelsen af kroppens forbundethed til et indre og ydre kosmos indebærer også, at kroppen ses som forbundet til andre liv, der manifesterer sig ,genetisk“i kroppen, der således er bærer af hændelser fra andre liv. Følgende meditationssekvens illustrerer dette:

I det polynesiske healingssystem er al kval, pine og smerte en henvendelse til kroppen eller til sindet fra sjælen. Disse henvendelser, disse erindringer kan handle om dine erfaringer i dette liv. De kan også være erfaringer, som du har haft i andre liv. I kraft af hukommelsen er de låst inde i sjælen, eller de kan være genetiske erindringer videreført fra generation til generation. Der er mange erindringer i din krop, mange erindringer. Og hver eneste smerte eller stump af glæde eller fryd, som du har i din krop handler om erindring. Tillad dit magtfulde ubevidste sind og din intuition at lade disse erindringer blive til visualiseringer... ${ }^{4}$

Den kropsepistemologi, som jeg har illustreret i det foregående, henter sin inspiration i maorimytologi, som i en dansk sammenhæng fortolkes og udlægges af maorihealeren. Dette er en etnisk dimension, der tilsyneladende får vidtrækkende konsekvenser for nogle Ma-uri-aktører. En Ma-uri-aktør kan således ligesom nogle maorier betragte sig selv som én, der nedstammer fra stjernerne. Antropologiens traditionelle forhold til myten som udtryk for en relativ virkelighedsopfattelse snarere end som virkelighed blev imødegået i en velkomsttale holdt af en ung mandlig maori ved modtagelsen af os danske Mauri-massører ved vores ankomst til New Zealand i 1993:

Vi maorier kommer fra stjernerne. Det er et faktum. De, der anvender betegnelsen myte for dette, er antropologer, som har opfundet ordet myte, fordi de ikke har evnen til at opfatte det som en realitet.

Som antropolog følte jeg mig naturligvis ramt af dette drøje hug fra en af de indfødte. Men det var som med Ma-uri-massagen - det gjorde ondt på en god måde, fordi det tvang mig til at forstå betydningen af, at maorisamfundet forsvarer de spirituelle aspekter af kulturen, der kommer til at fremstå som en magtfuld åndelig og symbolsk kapital. Maorierne er en kolonialiseret og marginaliseret befolkningsgruppe i New Zealand. Det er også en befolkning, som er bevidst om antropologiens rolle som fagdisciplin og erhvervsmulighed for ikke-maorier. Der hersker da også en udpræget skepsis, ja nærmest en fjendtlig indstilling over for hvide antropologers aktivitet i maorisamfundet. ${ }^{5}$ 


\section{Kroppen og naturen}

Ligesom kroppen iagttages som et mikrokosmos over for makrokosmos, så står den i et direkte forhold til naturen. Kroppen indgår således i en direkte dialog med naturen, hvilket blandt andet illustreres i en praksis, som Ma-uri-institutionen har indført i den danske sammenhæng. Teknikken er en meget konkret og direkte måde at etablere en dialog mellem kroppen og naturen. Ma-uri-aktører bliver bedt om at gå ud til et træ, omfavne det, og stille det ét spørgsmål $\mathrm{i}$ relation til vores situation lige her og nu. Vi får besked på at acceptere det første svar, der dukker op i bevidstheden, fremfor at vente til et mere bekvemt svar skulle dukke frem.

Teknikken betegnes af de fleste aktører som højst virkningsfuld. Det er en praksis, der for mange skaber indsigt, klarhed og tryghed accentueret af ideen om, at naturen altid har svaret. Det er også en praksis, der betragtes som velegnet til at skærpe opmærksomheden om egne indre ressourcer. Følgende beretning illustrerer, at indlæringsprocesser som de, der er beskrevet i det foregående, kan resultere i særegne kropsoplevelser og erfaringer, hvor kroppen og personen forvandles til et stykke natur, der træder i et direkte forhold til kosmos:

Under massagen oplever jeg, at det er to indianerpiger, der masserer mig. Jeg er en solbeskinnet slette. Det var så levende for mig, at jeg kunne lugte det tørre græs. Jeg var ved at blive gjort klar til bryllup med solen.

En kropsepistemologi, der indskriver kroppen i et direkte forhold til den ydre verden, står i skarp kontrast til en vestlig biomedicinsk kropsopfattelse, hvor kroppen ses som et finurligt sammensat maskinelt system (Scheper-Hughes \& Lock 1987:23). Opfattes kroppen i en medicinsk antropologisk terminologi som både en fysisk og kulturel „ting“, så er det ikke altid muligt at se, hvor naturen slutter, og kulturen begynder i de symbolske udtryk (ibid.:21).

Indlæringen af en kropsopfattelse, hvor kroppen står i et direkte forhold til den ydre verden, kan opleves som en vældig ekspansion af personlige muligheder og ressourcer, ligesom en sådan ekspansion kan give anledning til frygt, afmagt og svimmelhed. Det sidste får en del kursister til at forlade Ma-uri-institutionen. Disse personers erfaringer med Ma-uri-massagen og med Ma-uri-institutionen udgør væsentlige kilder til kritik af Ma-uri-healingsystemet. Det vil således være relevant at unders $\emptyset$ ge, i hvor høj grad kursister, der forlader uddannelsen i ,utide“, er i stand til at selv at håndtere deres eventuelt kritiske livssituation, eller om de står tilbage med mere afmagt, end de måske havde ved uddannelsens start.

\section{Perspektivering}

Ma-uri-massage er, som jeg har redegjort for i det foregående, en kropserfaring, hvis praksis udfordrer den vestlige krop/sjæl-dualisme. Ma-uri-massagen giver sine aktører kropserfaringer, der langt overskrider grænserne for, hvad der i et vestligt medicinsk system ville blive anset for normalt. Ved at sætte kroppen i et direkte forhold til naturen, kosmos og (maori)forfædrene udvider Ma-uri-massagen et vestligt normalitetsbegreb, i det mindste for Ma-uri-aktører. Gennem en terapeutisk indlæringsproces, hvor der an- 
vendes meditationer og modsætningsfyldte og til tider kaotiske undervisningssituationer, rystes aktørernes vante forestillinger og virkelighedsopfattelse i en grad, der kan sammenlignes med effekten af euforiserende stoffer.

Ma-uri-massagen er imidlertid mere end en alternativ kropsterapi. Den er funderet i en institution, der er kulturelt forankret i maorisamfundet, hvilket har væsentlig betydning for Ma-uri-massagen som kropserfaring og praksis. Ma-uri-institutionens virke er i sit udgangspunkt funderet i en maorihealers erfaring med maorisamfundet. Når Ma-uriinstitutionen arrangerer rejser til New Zealand for aktørerne, giver det en potentiel mulighed for at relatere viden og erfaringer som Ma-uri-aktør i en dansk virkelighed til virkeligheden i maorisamfundet. Dette indebærer yderligere en form for kulturel udveksling, hvor maorier og danske Ma-uri-aktører udveksler, udforsker og spejler hinanden igennem socialt samvær, samtaler og massage.

I dette forløb indgår danske Ma-uri-aktører uundgåeligt $i$ en etnisk og social proces i maorisamfundet, hvilket sker på flere niveauer: a) gennem healingteknikker, der har deres oprindelse i maorikultur og maorikosmologi, hvorved aktørernes kroppe kan få en direkte reference til maorisamfundet, b) i kraft af indlæringen af de sociale roller kan aktørerne få en social relation til maorisamfundet, der på sin side udfordrer og afprøver aktørernes roller, kropserfaringer og viden. Når aktørerne rejser til New Zealand, har det derfor øjensynligt en dobbeltfunktion: 1) som en yderligere aktivering af allerede indlærte healingsteknikker, og 2) som en aktivering af healingsprocesser i maorisamfundet. Begge dele accentueret af de danske Ma-uri-aktørers tilstedeværelse og aktivitet i maorisamfundet.

De erfaringer, jeg har præsenteret i denne artikel, peger på en medicinsk antropologisk undersøgelse af Ma-uri-massagen som kropserfaring, institution og terapeutisk praksis. Jeg vil derfor afslutningsvis skitsere nogle forslag til hovedtemaer for en sådan unders $\emptyset$ gelse: a) Ma-uri-aktørernes rekrutteringsgrundlag og motivation for valg af Ma-uri-massage som behandlingsform, b) Ma-uri-aktørernes vidensteknologi i den terapeutiske proces, herunder ,diagnoseprocessen“ samt fortolkningen af maorikosmologi, c) organiseringen af Ma-uri-institutionens aktiviteter og aktørernes erfaringer hermed, d) Ma-uri-aktørers og -klienters erfaringer med kroppen i healings- og sygdomsprocesser, e) maorisamfundets oplevelse og erfaring med danske Ma-uri-massører og deres aktiviteter.

\section{Noter}

1. For en nærmere redegørelse for healingtraditioner i maorisamfundet og de historiske vilkår herfor henvises til Blake Plamer 1954, Durie 1985, Voyce 1989, Buck 1910 og Weblemoe 1992. Endvidere henvises til King 1981, 1983, 1985 og 1990, der anvendes som grundlitteratur i uddannelsen af Ma-uri-massører.

2. For en klassisk antropologisk udlægning af maorimytologi se Best 1976 (1924). For en mere nutidig udlægning af maorikultur se antologien Te Ao Hurihuri redigeret af Michael King 1992.

3. This speech will be about opening up within your inner self. This speech will be about opening up your body and allowing every little cell, every being within your realm af your body, your universe, your body, every little cell to feel important and part of you the God Creator of your universe... You are not just the 
physical shape of how you are, you are a Universe. And as there are thousands and thousands of stars within the Universe, so in your body there are thousands and thousands of souls all within the realm of who they are. From an atom to a molecule, from a molecule to a grain of sand, from a grain of sand to a rock, and from a rock to a beach, from a beach to an island in the sea, and from a sea within an ocean, from an ocean within a world, a world within a solarsystem, and a solarsystem within a galaxy within a universe, and a universe within a unitrone, and a unitrone within a uniarc, and that is the nucleus of creation of an atom to a molecule to a grain of sand...

4. In the Polynesian healinsystem all agony, all pain is a message about the body, about the mind or from the soul. These messages, these memories can be about experiences you've had within the living, the living memory of this life. They can be experiences that you've had within other lives. Through the memory locked within the soul, or they could be genetic memories handed down generation by generation. There are many memories within your body, many memories. And each pain, each piece of joy and happiness you have within your body is about a memory. Allow your powerful subconscious mind and your intuition to let these memories become a vision...

5. Allan Hansson (1989) præsenterer en kritisk gennemgang af vestlige antropologers og historikeres udlægning af maorikultur og -tradition samt af maorisamfundets dilemma ved at være forbundet til en vestlig videnskabelig tradition for etablering af en identitet som folk.

\section{Litteratur}

Best, Elsdon

1976 [1924] Maori Religion and Mythology 1-2. Auckland.

Buck, Peter

1910 Medicine amongst the Maoris in Ancient and Modern Times. Upubliceret doktorafhandling, University of New Zealand.

Cowperthwaite, Valerie

1992 Total Control. From Entertainer to Counsellor, Te Hata has Travelled far to Interpret the Teachings of his Culture. Rainbow Network.

Durie, M. H.

1989 A Maori Perspective of Health. Social Science and Medicine 20(5).

Foucault, Michel

1973(1965) Madness and Civilisation. New York.

Hansson, Allan

1989 The Making of the Maori. Culture Invention and Its Logic. American Anthropologist 91.

King, Michael

1992 Te Ao Hurihuri. Aspects of Maoritanga. Auckland.

King, Serge

1981 Imagineering for Health. Illinois.

1983 Kahuna Healing. Illinois.

1985 Mastering your Hidden Self. Illinois.

1990 Urban Shaman. New York.

Palmer, G. Blake

1954 Tohungaism and Makutu. Journal of Polynesian Society 6(1).

Rabinow, Paul

1977 Reflections on Fieldwork in Morocco. London. 
Scheper-Hughes, Nancy \& Margaret M. Lock

1987 The Mindful Body: A Prolegomenon to Future Work in Medical Anthropology. Medical Anthropology Quarterly 1.

Voyce, Malcom

1989 Maori Healers in New Zealand: The Tohunga Suppression Act 1907. Oceania 60.

Weblemoe, Terry

1993 A Binocular Perspective af the Social Factors Influencing Maori Health and Health Care. Upubliceret afhandling, University of Auckland. 
